\title{
Combining Brachytherapy and Cryotherapy as Adjuvant Therapy for Squamous Cell Carcinoma of the Conjunctiva: Literature Review and Case Reports
}

\author{
Peter S. Fagerberg ${ }^{a}$ Ingvild M.S. Ramberg ${ }^{b}$ Peter B. Toft ${ }^{a, c}$

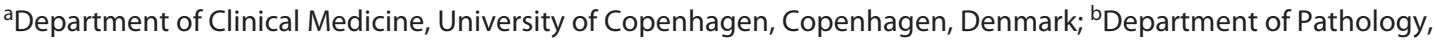 \\ Copenhagen University Hospital Rigshospitalet, Copenhagen, Denmark; 'Department of Ophthalmology, \\ Copenhagen University Hospital Rigshospitalet, Copenhagen, Denmark
}

\section{Keywords}

Adjuvant therapy · Brachytherapy - Cryotherapy ·

Squamous cell carcinoma $\cdot$ Conjunctiva results by combining the 2 adjuvant therapies showing no signs of recurrence or complications during a follow-up period of 26 and 38 months.

\begin{abstract}
Background: Separately, cryotherapy and brachytherapy have shown promising results when adjuvating the excision of squamous cell carcinoma of the conjunctiva (SCCC). The aim of this paper is to assess the combined effect in terms of complications and recurrence rate. Summary: We describe 2 patients suffering from SCCC, and we review the current literature on adjuvant cryotherapy and brachytherapy. Both patients, one of whom suffered from recurrent SCCC, underwent surgical excision followed by combined cryotherapy and brachytherapy. Cryotherapy was performed using a retinal cryoprobe, and 2 rounds each of $5 \mathrm{~s}$ with $\mathrm{N}_{2} \mathrm{O}$ as a cryogen were applied. Brachytherapy was performed using a ruthenium-106 plaque, delivering a dosage of $100 \mathrm{~Gy}$ at 2-mm depth. Key Messages: By reviewing the current literature and describing 2 case reports, this paper illustrates the use of combined cryotherapy and brachytherapy after surgical excision of SCCC. The current literature presents promising results of each treatment, and the 2 cases showed promising
\end{abstract}

\section{Introduction}

Squamous cell carcinoma of the conjunctiva (SCCC) is the most common conjunctival malignancy in the world. As the incidence of SCCC declines by $49 \%$ for each $10^{\circ}$ increase in latitude [1], the isolated incidence rate is 0.02 per 100,000 men and 0.008 per 100,000 women per year in Denmark (55-57 north), correlating well with other studies in northern, high-latitude areas [2].

At such latitudes, SCCC is primarily found in Caucasian men above 60 years of age, located at the nasal or temporal conjunctiva in the interpalpebral region close to the limbus. The most characteristic clinical appearance is a nonpigmented, irregularly shaped growth, with a thickness above $1 \mathrm{~mm}$ with feeder and/or intrinsic vessels [3].

Disease control of up to $100 \%$ has been reported when SCCC is treated using excision with clear surgical margins, while the recurrence rate with residual tumor cells karger@karger.com

(C) 2021 S. Karger AG, Basel

www.karger.com/oop

Karger"
Peter S. Fagerberg

Department of Clinical Medicine

University of Copenhagen, Blegdamsvej 3B

DK-2200 Copenhagen $\varnothing$ (Denmark)

pfpost@live.dk 
of the margins may be as high as 53\% [4]. When adjuvating surgical excision of SCCC with cryotherapy, reported recurrence rates vary from 0 to $50 \%$ [5-10]. Brachytherapy is also used as adjuvant therapy of excision, resulting in recurrence rates of $0-20 \%$ [11-19].

This paper reviews the literature on adjuvant cryotherapy and brachytherapy to assess the combined effect, which could result in further reduction of recurrence rates. Two case reports are described, in one of which the patient suffered from recurrent SCCC. Both cases were treated with excision adjuvated by combined cryotherapy and brachytherapy using 2 rounds of $5 \mathrm{~s}$ with $\mathrm{N}_{2} \mathrm{O}$ as a cryogen and a 15.3-mm ruthenium-106 (Ru-106) plaque, due to the recurrent disease (pt. 1) or large tumor size (pt. 2). No complications or recurrences were observed during follow-up periods of 26 and 38 months.

\section{Methods}

This study includes 2 patients suffering from bulbar SCCC. Both patients were treated with surgical excision followed by adjuvant cryo- and brachytherapy at our institution in the years 2016-2019. Written informed consent to publish clinical photographs was obtained from both patients.

A PubMed search was performed on English publications, using the terms "squamous cell carcinoma," "conjunctival cancer," "corneal cancer," "conjunctival tumor," "corneal tumor," "squamous neoplasia," "squamous cell neoplasia," "SCCC," "plaque therapy," "brachytherapy*," "surface radiotherapy," "conjunctiva*," "cornea*," "orbital*," and "ophthalmological*." Furthermore, the abovementioned terms were combined using the MeSH terms "conjunctival neoplasms" and "brachytherapy." The resulting articles were reviewed for similar articles. When relevant studies were found, a manual search of references was conducted. Studies were excluded if data on SCCC in terms of recurrence rates and complications were not specified.

\section{Case Presentations}

\section{Case 1}

An 88-year-old male presented with a greyish, elevated tumor located temporally in the left conjunctiva covering part of the cornea (shown in Fig. 1). The patient had undergone bilateral cataract surgery at the age of 82 , but the visual acuity of the left eye after cataract surgery was only 0.17 due to epiretinal fibrosis.

At presentation, visual acuity measured $1 / 60$ on the left eye compared to $6 / 12$ on the right eye. A squamous cell carcinoma at the same location had been excised 3 years prior without adjuvant therapy.
Before surgery, photo documentation was performed, while neither optical coherence tomography (OCT) or ultrasound biomicroscopy (UBM) was performed. The excision of the recurrent lesion comprised alcohol-assisted epitheliectomy and release of the tumor from the cornea followed by sharp excision of the conjunctival tumor, stopping at bare sclera.

The conjunctival surgical margin was marked using bipolar diathermia aiming at a 3-mm margin to the tumor. Lamellar scleral excision was not performed, though advised by authorities [20]. Frozen sections of the conjunctival margins and scleral base were not performed. The tumor was easily released from its scleral base, showing no signs of scleral invasion.

Cryotherapy of the conjunctival margins was performed using a retinal cryoprobe, and 2 rounds of freezing each of $5 \mathrm{~s}$ with $\mathrm{N}_{2} \mathrm{O}$ as a cryogen were performed. After cryotherapy, a $\mathrm{Ru}-106$ plaque was sutured over the tumor site for a total of $28 \mathrm{~h}$, resulting in a calculated tissue deposit of $100 \mathrm{~Gy}$ at 2-mm depth and a maximum dose of $237 \mathrm{~Gy}$ at the scleral bed. The use of brachytherapy was based on the recurrence of SCCC.

Histopathological examination showed a polypoid process consisting of pleomorphic and hyperplastic squamous tumor cells with several atypical mitoses. The tumor was well differentiated with intercellular bridges and keratinization and invaded the underlying inflamed stroma. The diagnosis of SCCC was confirmed by immunohistochemistry using anti-cytokeratin (CK) 5 and anti$\mathrm{p} 40$. The human papillomavirus (HPV) surrogate marker p16 and HPV DNA polymerase chain reaction (PCR) were both negative. The surgical margins could not be evaluated. Clinical examination 26 months later showed no evidence of recurrence, and the visual acuity of the left eye was $0.5 / 60$.

\section{Case 2}

A 64-year-old male presented with a pale, solid tumor at the temporal corneal limbus with moderate ciliary injection (shown in Fig. 2). The tumor measured $6.5 \times 5.5$ $\mathrm{mm}$. One month prior, the patient started experiencing irritation with redness laterally in the right eye. A week later, the patient noticed a rapidly growing tumor. Visual acuity measured $6 / 10$ on the left eye and $6 / 6$ on the right.

Before surgery, photo documentation was performed, while neither OCT or UBM was executed. The excision comprised alcohol-assisted epitheliectomy and release of the tumor from the cornea followed by sharp excision of the conjunctival tumor, stopping at bare sclera. 

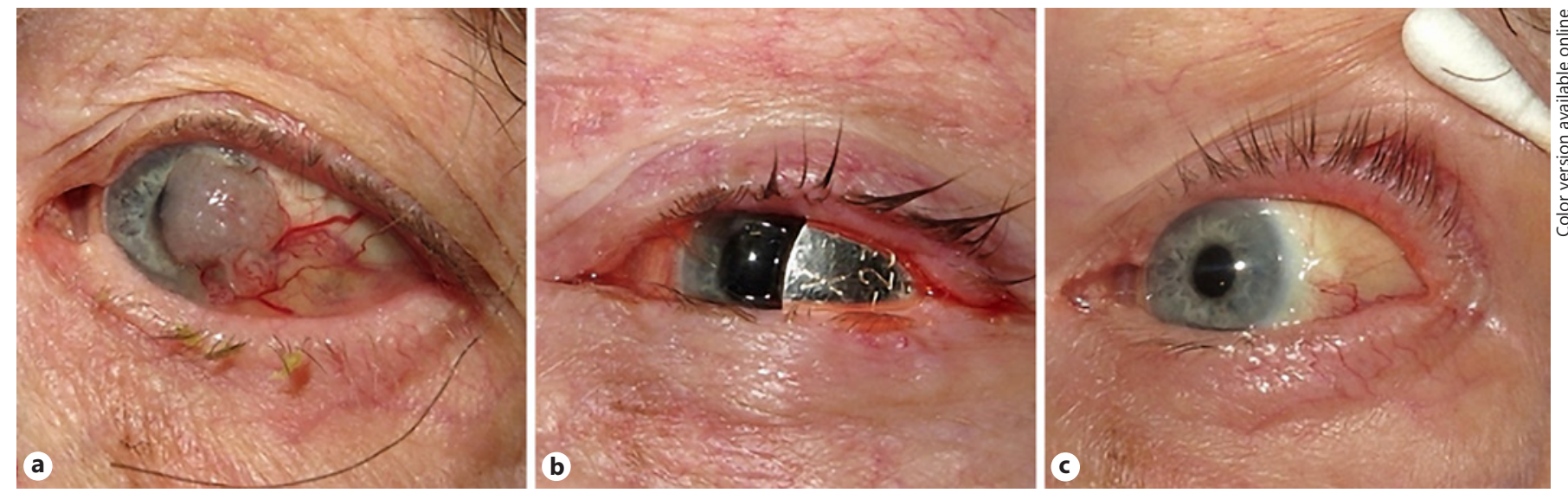

Fig. 1. Squamous cell carcinoma of the conjunctiva treated with excision, cryotherapy, and a ruthenium plaque. a An 88-year-old male presented with a tumor located to the temporal corneal limbus. b Excisional biopsy was performed followed by cryotherapy and suture of a ruthenium plaque over the tumor bed. The plaque was removed after $100 \mathrm{~Gy}$ had been delivered at 2-mm depth. c At 4 months, the eye was almost calm, with no sign of early recurrence.
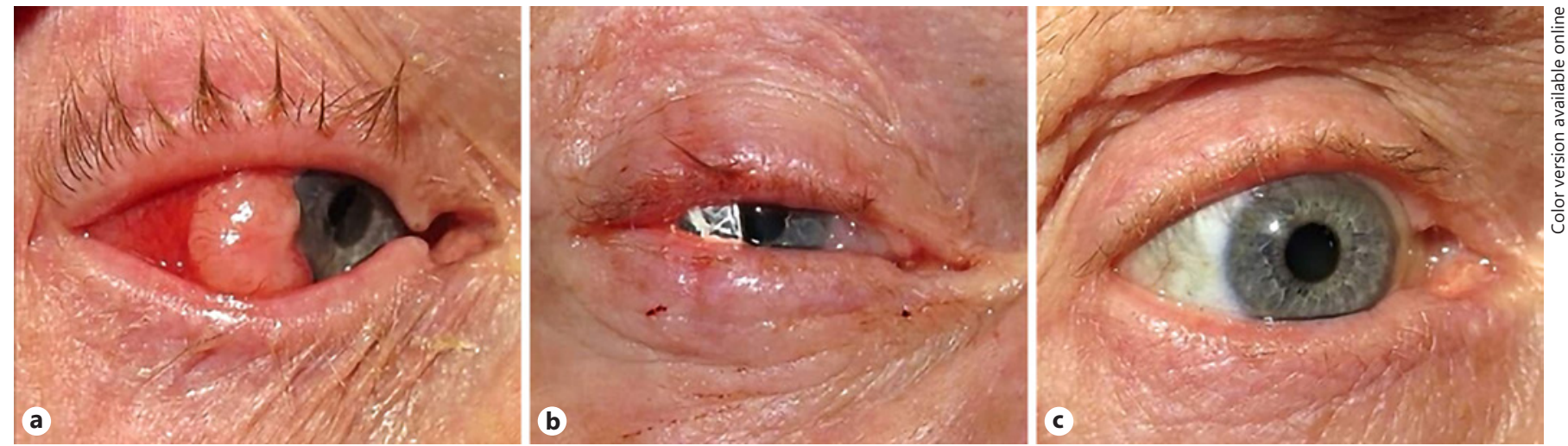

Fig. 2. Squamous cell carcinoma of the conjunctiva treated with excision, cryotherapy, and a ruthenium plaque. a A 64-year-old male presented with a temporally located tumor on the right eye just crossing the limbus with ciliary injection. b Excisional biopsy was performed followed by cryotherapy and suture of a ruthenium plaque over the tumor bed. The plaque was removed after $100 \mathrm{~Gy}$ had been delivered at 2-mm depth. c At 3-year followup, there had been no sign of recurrence.

The conjunctival surgical margin was marked using bipolar diathermia aiming at a 3-mm margin to the tumor. Lamellar scleral excision was not performed, though advised by authorities [20]. Frozen sections of conjunctival margins and scleral base were not performed. The tumor was easily released from its scleral base, showing no signs of scleral invasion.

Cryotherapy of the conjunctival margins was performed using a retinal cryoprobe, and 2 rounds of freezing each of $5 \mathrm{~s}$ with $\mathrm{N}_{2} \mathrm{O}$ as a cryogen were performed.
After cryotherapy, a Ru-106 plaque was sutured over the tumor site for a total of $19 \mathrm{~h}$, resulting in a calculated tissue deposit of $100 \mathrm{~Gy}$ at 2-mm depth and a maximum dose of $239 \mathrm{~Gy}$ at the scleral bed. The use of brachytherapy was based on the size of the tumor.

Histopathological examination showed a tumor composed of well-differentiated, squamous tumor cells. Infiltrative islands were seen in the underlying desmoplastic stroma. There were multiple squamous eddies and atypical mitoses present in the tumor tissue. By immunohisto- 
Table 1. Literature review (1989-2020) reporting the use of cryotherapy as adjuvant treatment when exciding squamous cell carcinoma of the conjunctiva

\begin{tabular}{|c|c|c|c|c|c|c|c|c|c|c|}
\hline $\begin{array}{l}\text { Author } \\
\text { country }\end{array}$ & $N$ & Histology & $\begin{array}{l}\text { Cryotherapy } \\
\text { (cryogen) }\end{array}$ & $\begin{array}{l}\text { Median age, } \\
\text { years }\end{array}$ & $\begin{array}{l}\text { LR, } \\
n(\%)\end{array}$ & $\begin{array}{l}\text { LR of } \\
\text { SCCC, } \\
n(\%)\end{array}$ & $\begin{array}{l}\text { Primary } \% \\
\text { of LR SCCC, } \\
n(\%)\end{array}$ & $\begin{array}{l}\text { Salvage \% } \\
\text { of LR SCCC, } \\
n(\%)\end{array}$ & $\begin{array}{l}\text { Mean } \\
\text { follow-up, } \\
\text { months }\end{array}$ & Complications \\
\hline $\begin{array}{l}\text { Peksayar et al. [7] } \\
\text { Turkey }\end{array}$ & 22 & $\begin{array}{l}12 \text { SCCC } \\
10 \mathrm{CIN}\end{array}$ & $\begin{array}{l}+ \text { Margins } \\
+ \text { Scleral bed } \\
\left(\mathrm{N}_{2} \mathrm{O}\right)\end{array}$ & 59.7 & $2(9)$ & $2(16.7)$ & $1(50)$ & $1(50)$ & 72 & $\begin{array}{l}5 \text { minimum corneal scarring } \\
2 \text { sectoral iris atrophy } \\
2 \text { temporary ocular hypertension } \\
1 \text { temporary ocular hypotension } \\
1 \text { corneal hemorrhage } \\
1 \text { superficial corneal vascularization }\end{array}$ \\
\hline $\begin{array}{l}\text { Tunc et al. [10] } \\
\text { USA }\end{array}$ & 60 & $\begin{array}{l}38 \text { SCCC* } \\
22 \text { CIN }\end{array}$ & $\begin{array}{l}+ \text { Margins } \\
+ \text { Scleral bed } \\
\text { (NR) }\end{array}$ & 64 & $3(5)$ & $2^{*}(8.3)$ & Nil & $2(100)$ & 56 & $\begin{array}{l}4 \text { mild symblepharon } \\
2 \text { graft contractions } \\
2 \text { pannus } \\
1 \text { dellen } \\
1 \text { corneal scarring } \\
1 \text { hypertropia } \\
1 \text { descemetocele } \\
1 \text { astigmatism }\end{array}$ \\
\hline $\begin{array}{l}\text { Sudesh et al. [9] } \\
\text { USA }\end{array}$ & 28 & $\begin{array}{l}18 \mathrm{CIS} \\
7 \mathrm{D} \\
2 \mathrm{SCCC} \\
1 \mathrm{AK}\end{array}$ & $\begin{array}{l}+ \text { Margins } \\
\text { - Scleral bed } \\
\left(\mathrm{N}_{2} \mathrm{O}\right)\end{array}$ & 66 & $5(17.9)$ & $1(50)$ & Nil & $1(100)$ & 38 & Nil \\
\hline $\begin{array}{l}\text { Sturges et al. [8] } \\
\text { USA }\end{array}$ & 14 & $\begin{array}{l}10 \mathrm{CIN} \\
4 \mathrm{SCCC}\end{array}$ & $\begin{array}{l}\text { + Margins } \\
\text { - Scleral bed } \\
\text { (NR) }\end{array}$ & $63.9^{\mathrm{m}}$ & Nil & Nil & Nil & Nil & 35.6 & Nil \\
\hline $\begin{array}{l}\text { Palamar et al. [6] } \\
\text { Turkey }\end{array}$ & 21 & $\begin{array}{l}10 \text { SCCC } \\
9 \mathrm{CIN} \\
2 \mathrm{D}\end{array}$ & $\begin{array}{l}+ \text { Margins } \\
\text { - Scleral bed } \\
\text { (NR) }\end{array}$ & $62.4^{\mathrm{m}}$ & Nil & Nil & Nil & Nil & 30.9 & $\begin{array}{l}3 \text { partial limbal stem cell deficiency } \\
1 \text { symblepharon }\end{array}$ \\
\hline $\begin{array}{l}\text { Li et al. [5] } \\
\text { USA }\end{array}$ & 43 & $\begin{array}{l}24 \mathrm{CIS} \\
14 \mathrm{D} \\
5 \mathrm{SCCC}\end{array}$ & $\begin{array}{l}\text { + Margins } \\
\text { - Scleral bed } \\
\text { (NR) }\end{array}$ & 69 & $3(7)$ & Nil & Nil & Nil & $29^{\mathrm{md}}$ & NR \\
\hline $\begin{array}{l}\text { Current study (2020) } \\
\text { Denmark }\end{array}$ & 2 & $2 \mathrm{SCCC}$ & $\begin{array}{l}+ \text { Margins } \\
\text { - Scleral bed } \\
\left(\mathrm{N}_{2} \mathrm{O}\right)\end{array}$ & 76 & Nil & Nil & Nil & Nil & $26-38$ & Nil \\
\hline$N$ & 190 & 59 SCCC & & - & $13 / 190(6.8)$ & $5 / 59(8.5)$ & $1 / 5(20)$ & $4 / 5(80)$ & - & - \\
\hline
\end{tabular}

m , mean; ${ }^{\mathrm{md}}$, median; $n$, number of cases; LR, local recurrence; Primary, first treatment; Salvage, recurrent treatment; SCCC, squamous cell carcinoma of the conjunctiva; CIN, conjunctival intraepithelial neoplasia D, dysplasia; AK, actinic keratosis; CIS, carcinoma in situ; NR, not reported. * 24 of 38 SCCC patients received adjuvant cryotherapy.

chemistry, the tumor cells were positive in pan-CK and negative in Melan-A, confirming the diagnosis of SCCC. The surgical margins could not be evaluated. Two months later, visual acuity of both eyes measured $6 / 6$. Follow-up after 38 months showed no evidence of recurrence.

\section{Discussion}

We describe 2 cases of SCCC in the limbal region, one of which suffered from recurrent SCCC. Both cases presented with characteristic clinical findings. Both patients were Caucasian males above 60 years of age and had tumors located at the temporal conjunctiva of the interpalpebral region in proximity of the limbus. Both tumors appeared nonpigmented with an irregular growth, vessel formation, and a papilliform surface.

The 2 cases were successfully treated with excision adjuvated by cryotherapy and plaque brachytherapy using a 106-ruthenium plaque. In both cases, the adjuvant effect of combining cryo- and brachytherapy controlled the site of concern, effectively delivering its radioactive dose in 28 and $19 \mathrm{~h}$, respectively. We used Ru-106 plaques due to its frequent use when treating ocular malignant melanomas, thus making it the available type of brachytherapy in our institution.

Surgical excision of SCCC is usually combined with adjuvating therapies such as cryotherapy, topical mitomycin C, topical 5-fluorouracil, or interferon- $\alpha 2 \beta$ [21]. Furthermore, several radiotherapeutic treatments have been suggested, including brachytherapy [22].

\section{Adjuvant Cryotherapy}

Adjuvating the excision of SCCC with double freezethaw cryotherapy to the surgical margins is considered the gold standard [20] and probably the most commonly used adjuvant treatment of SCCC (Table 1) [5-10]. However, some studies $[7,10]$ also include the scleral base when adjuvating surgical excision with cryotherapy. The 
adjunctive effect of cryotherapy is due to obliteration of the microcirculation, which leads to ischemic infarction of the surrounding tissue $[23,24]$.

The literature describes 59 cases of SCCC treated with surgical excision followed by adjuvant cryotherapy. Of those 59 SCCC cases, 5 recurred during variable follow-up periods, resulting in an average recurrence rate of SCCC managed by excision adjuvated by cryotherapy of $8.5 \%$ (Table 1). Reports of local recurrence range from 0 to $16.7 \%$ in most cases, while Sudesh et al. [9] reported recurrence in 1 of 2 salvaged SCCC patients (50\%). The percentage of reported SCCC recurrences relies heavily upon whether patients underwent primary (20\%) or salvage treatment (80\%), highlighting the importance of lowering the primary recurrence rate as much as possible in the first place, in order to reduce the need for salvage treatment.

Several studies report the potential complications of cryotherapy, presenting as corneal inflammation and scarring, symblepharon, pannus formation, sectoral iris atrophy, corneal hemorrhage, descemetocele, and astigmatism $[6,7,10]$. If cryotherapy is extensively used near the limbus, it may lead to limbal stem cell insufficiency [25], as observed by Palamar et al. [6]. In our 2 cases, no complications of cryotherapy were reported within the follow-up periods, possibly because cryotherapy was applied only to the conjunctival margins and not to the sclera or cornea.

\section{Adjuvant Brachytherapy}

When treating SCCC with excision, brachytherapy is also used as an adjuvant therapy. After excision of conjunctival or corneal tumors, the tumor bed can be treated using a number of radioactive sources such as strontium-90 (Sr-90), iodine-125 (I-125), or ruthenium-106 (Ru-106) [22]. Other radiotherapeutic options, such as electron- and proton-beam radiotherapy, have also shown promising results, with reported disease control in up to $100 \%$ of cases [14, 26-28].

$\mathrm{Ru}-106$ is a beta emitter with a half-life of 374 days. With a tissue penetration (half-value layer $[\mathrm{HVL}]=2.4$ $\mathrm{mm})$ in between those of $\mathrm{Sr}-90(\mathrm{HVL}=1.5 \mathrm{~mm})$ and $\mathrm{I}-125(\mathrm{HVL}=20 \mathrm{~mm})$, the useful range of $\mathrm{Ru}-106$ is 5-6 $\mathrm{mm}$, compared to $2 \mathrm{~mm}$ for Sr-90 and $13 \mathrm{~mm}$ for I- 125 [22]. When using Sr-90, the radioactive dose is delivered by a handheld device, while both Ru-106 and I-125 are sutured to the ocular surface, allowing a more precise plaque localization [19]. Because the radioactive isotope in the standard $\mathrm{Ru}-106$ and I-125 plaques is attached to the concave surface of the plaque, the use of such plaques is limited to bulbar malignancies and can-

Combined Adjuvant Therapy of SCCC not be used for SCCC located in the fornices or in the tarsal conjunctiva.

The specific usage of Ru-106 brachytherapy has previously been reported by Zehetmayer et al. [19] in 1993 as well as Kenawy et al. [14] in 2015. Zehetmayer et al. [19] described 2 cases, one of which suffered from SCCC. With a dosage of $240 \mathrm{~Gy}$ at $1 \mathrm{~mm}$, they had no sign of recurrence in 22 months but did report scleral rarefaction as a complication. Kenawy et al. [14] opted for $100 \mathrm{~Gy}$ at $1 \mathrm{~mm}$ for both primary and salvage SCCC. In a total of 19 cases, they reported no recurrences or long-term ocular complications at follow-up medians of 69 months (primary group) and 55 months (salvage group).

Based on these limited data, it seems reasonable to assume that a higher dosage of radiation increases the risk of radiotherapeutic complications. While the literature on $\mathrm{Ru}-106$ brachytherapy is scarce, there seems to be a consensus in the effectiveness of brachytherapy in general. The available literature on the treatment of SCCC is based on case series, leaving an optimal line of treatment undetermined, since no comparative studies exist.

The literature describes 116 cases of SCCC treated with surgical excision followed by adjuvant brachytherapy. Of those 116 SCCC cases, 7 recurred during variable follow-up periods, resulting in an average recurrence rate of SCCC managed by excision adjuvated by brachytherapy of $6.0 \%$ (Table 2) [11-19]. Most studies report recurrence rates of $0-14.8 \%$, while Laskar et al. [15] reported recurrence in 2 of 10 SCCC patients (20\%).

Complications of brachytherapy are well known, presenting as radiation conjunctivitis, dry eye, uveitis, cataract, scarring, symblepharon, ulceration, scleral or corneal thinning, corneal perforation, keratopathy, glaucoma, and retinopathy $[16,18,29]$. In our case series, no complications due to brachytherapy were reported.

Since the lens is the most radiosensitive structure of the eye, cataract presents as one of the most common complications of brachytherapy [11]. However, both cataract and glaucoma seem to occur more often in older individuals receiving brachytherapy. In 2015, Lecuona et al. [16] had no reports of cataract in their 69 cases, which correlates well with the low median age of 42 years in their series.

In general, the use of plaque radiotherapy provides a very focused radioactive deposit on targeted tissue, minimizing the irradiation of surrounding and deeper tissue. It also eliminates the dependency of patient compliance, as is the case with other adjunctive treatments such as topical chemotherapy. However, sizing the plaque correctly is paramount in terms of recurrence. In 2015, Lecuona et al. [16] noted the importance of plaque sizing in 
Table 2. Literature review (1976-2020) reporting the use of brachytherapy as adjuvant treatment of squamous cell carcinoma of the conjunctiva

\begin{tabular}{|c|c|c|c|c|c|c|c|c|c|}
\hline $\begin{array}{l}\text { Author } \\
\text { country }\end{array}$ & $N$ & Histology & Median age & Emitter & Dose & $\begin{array}{l}\text { Total LR, } \\
n(\%)\end{array}$ & $\begin{array}{l}\text { SCCC LR, } \\
n(\%)\end{array}$ & $\begin{array}{l}\text { Median follow-up, } \\
\text { months }\end{array}$ & Complications \\
\hline $\begin{array}{l}\text { Lommatzsch [17] } \\
\text { Germany }\end{array}$ & 15 & $\begin{array}{l}10 \text { SCCC } \\
4 \mathrm{CIN} \\
1 \mathrm{EP}\end{array}$ & 64.2 & $\begin{array}{l}\text { Strontium-90/ } \\
\text { yttrium-90 }\end{array}$ & $100-180 \mathrm{~Gy}$ & $1(6.7)$ & Nil & $12-96$ & $\begin{array}{l}\mathrm{X} \text { transitory irritation } \\
3 \text { corneal scarring } \\
1 \text { cataract } \\
1 \text { triangular opacity } \\
1 \text { partial symblepharon } \\
1 \text { secondary glaucoma }\end{array}$ \\
\hline $\begin{array}{l}\text { Kearsley et al. [13] } \\
\text { Australia }\end{array}$ & 140 & $\begin{array}{l}78 \text { CIS } \\
62 \text { SCCC }\end{array}$ & 56 & Strontium- $90^{\mathrm{a}}$ & $31 \mathrm{~Gy}^{\mathrm{m}}$ & $3(2.4)^{\mathrm{a}}$ & NR & 97 & $\begin{array}{l}\mathrm{X} \text { transitory irritation } \\
3 \text { telangiectasia } \\
2 \text { scleral defects } \\
2 \text { cataract }\end{array}$ \\
\hline $\begin{array}{l}\text { Cerezo et al. [12] } \\
\text { Spain }\end{array}$ & 27 & $\begin{array}{l}15 \mathrm{IE} \\
12 \mathrm{SCCC}\end{array}$ & 63 & Strontium-90 & $\begin{array}{l}60 \mathrm{~Gy}^{\mathrm{SDT}} \\
140 \mathrm{~Gy}^{\mathrm{Fr}}\end{array}$ & $4(14.8)$ & $1(8.3)$ & $24-180$ & $\begin{array}{l}\mathrm{X} \text { transitory irritation } \\
5 \text { cataract }\end{array}$ \\
\hline $\begin{array}{l}\text { Zehetmayer et al. [19] } \\
\text { Austria }\end{array}$ & 2 & $\begin{array}{l}1 \mathrm{CM} \\
1 \mathrm{SCCC}\end{array}$ & $72.5^{\mathrm{m}}$ & Ruthenium-106 & $\begin{array}{l}\text { CM } 200 \text { Gy } \\
\text { SCC } 240 \text { Gy }\end{array}$ & Nil & Nil & $36^{\mathrm{m}}$ & $\mathrm{X}$ scleral rarefaction \\
\hline $\begin{array}{l}\text { Walsh-Conway et al. [18] } \\
\text { Australia }\end{array}$ & 11 & $\begin{array}{l}5 \mathrm{CM} \\
6 \mathrm{SCCC}\end{array}$ & 60.8 & Iodine-125 & $100 \mathrm{~Gy}$ & Nil & Nil & 23.4 & $\begin{array}{l}5 \text { corneal ulceration } \\
4 \text { reduced peripheral corneal } \\
\text { vascularization }\end{array}$ \\
\hline $\begin{array}{l}\text { Arepalli et al. [11] } \\
\text { USA }\end{array}$ & 15 & 15 SCCC & 70 & Iodine-125 & $\begin{array}{l}56 \mathrm{~Gy} \mathrm{apex}^{\mathrm{m}} \\
95 \mathrm{~Gy} \mathrm{base}^{\mathrm{m}}\end{array}$ & Nil & Nil & 42 & $\begin{array}{l}13 \text { cataract } \\
5 \text { telangiectasia } \\
4 \text { corneal defect } \\
3 \text { corneal edema } \\
1 \text { glaucoma }\end{array}$ \\
\hline $\begin{array}{l}\text { Kenawy et al. [14] } \\
\text { UK }\end{array}$ & 41 & $\begin{array}{l}\text { Primary treatment: } \\
9 \text { SCCC } \\
11 \text { CIS } \\
\text { Salvage treatment: } \\
10 \text { SCCC } \\
11 \text { CIS }\end{array}$ & 63 & Ruthenium-106 & $100 \mathrm{~Gy}$ & $3(7.3)$ & Nil & $\begin{array}{l}\text { Primary: } 69 \\
\text { Salvage: } 54.5\end{array}$ & Nil \\
\hline $\begin{array}{l}\text { Laskar et al. [15] } \\
\text { India }\end{array}$ & 13 & $\begin{array}{l}10 \text { SCCC } \\
1 \text { MGC } \\
1 \text { BK } \\
1 \text { MALT-L }\end{array}$ & 47 & Strontium-90 & $30-50 \mathrm{~Gy}^{\mathrm{Fr}}$ & $2(20)$ & $2(20)$ & 51 & $\begin{array}{l}4 \text { telangiectasia } \\
1 \text { limbal scar } \\
1 \text { limbal opacification }\end{array}$ \\
\hline $\begin{array}{l}\text { Lecuona et al. [16] } \\
\text { South Africa }\end{array}$ & 69 & $\begin{array}{l}41 \text { SCCC } \\
28 \text { CIS }\end{array}$ & 42 & Strontium-90 & $60 \mathrm{~Gy}^{\mathrm{Fr}}$ & $8(11.6)$ & $4(9.8)$ & 27 & $\begin{array}{l}5 \text { dry eye } \\
1 \text { astigmatism }\end{array}$ \\
\hline $\begin{array}{l}\text { Current study (2020) } \\
\text { Denmark }\end{array}$ & 2 & 2 SCCC & $76^{\mathrm{m}}$ & Ruthenium-106 & $100 \mathrm{~Gy}$ & Nil & Nil & $26-38$ & Nil \\
\hline$N$ & 335 & $116 \mathrm{SCCC}^{\mathrm{b}}$ & - & - & - & $21 / 335=6.3 \%$ & $7 / 116=6.0 \%$ & - & - \\
\hline
\end{tabular}

relation to recurrence rates, finding recurrence rates of $0 \%$ when using $18-\mathrm{mm}$ plaques and $16.3 \%$ when using $8.5-\mathrm{mm}$ plaques. Recurrences were caused by edge-recurrence due to a smaller active field of radiation.

Combining Adjuvant Cryotherapy and Brachytherapy

Separately, the use of adjuvant cryotherapy and adjuvant brachytherapy lowers the recurrence rate of SCCC. The goal of combining them is to further increase their potency while keeping complications at a minimum.

The amount of literature on the combined use of cryotherapy and brachytherapy in an adjuvant setting is extremely limited, even though both modalities are widely available and commonly used. Of the 9 reviewed studies listed in Table 2, only Arepalli et al. [11] and the present study used a combination of the 2 therapies. In the study by Arepalli et al. [11], the choice of combination was based on histopathological confirmation of invasion of the sclera and/or anterior chamber after initial treatment of excisional biopsy, superficial keratectomy, and conjunctival cryotherapy. Their choice of emitter was I-125, delivering a mean apex dose of $56 \mathrm{~Gy}$ and a mean base dose of $95 \mathrm{~Gy}$ for a mean duration of $132 \mathrm{~h}$. Radiationinduced complications were numerous, including cataract, telangiectasia, epithelial defects, corneal edema, and glaucoma (Table 1). However, of the 15 cases treated, no local recurrences were reported. It is worth noting that most of the cases were referred due to recurrence of SCCC $(n=10)$, making the local recurrence rate of $0 \%$ even more prominent. 
In our study, the decision of combining adjuvant cryotherapy and brachytherapy was based on the recurrent disease of case 1 and the tumor size of case 2 . When combining therapies in this manner, it is crucial to consider the fact that the patients are subjected to the complications of both treatments, which must be outweighed by the reduction of recurrences. In our 2 cases, no complications or recurrences were reported after combining surgical excision with adjuvant cryotherapy and brachytherapy within follow-up periods of 26 and 38 months.

\section{Conclusion}

The combined effect of adjuvant cryotherapy and brachytherapy is difficult to determine from the literature due to the rare occurrence of SCCC. Adding the lack of consensus regarding treatment regimens and adjuvating modalities makes it even more difficult to determine the combined effect [30].

Opting for a combined adjuvant therapy may lower the recurrence rate of SCCC. However, this advantage must be weighed against a possible increase in severe complications from subjecting the patients to both cryotherapy and brachytherapy.
While our study is not sufficiently powered to draw any conclusions, it is our hope that the presented cases increase the awareness of combining adjuvant cryotherapy and brachytherapy for bulbar SCCC and that they result in further studies of the combined effect of adjuvant therapies.

\section{Conflict of Interest Statement}

The authors have no conflicts of interest to declare.

\section{Funding Sources}

No funding was received in relation to this study.

\section{Author Contributions}

P.S.F. (Bachelor of Medicine) wrote the manuscript, receiving substantial contribution from I.M.S.R. (medical doctor) and P.B.T. (medical doctor, Doctor of Medical Science) on the acquisition of cases as well as analysis and data interpretation of the work. P.S.F., I.M.S.R., and P.B.T. critically revised the drafts, approved the final version before publication, and agreed on accountability regarding the accuracy and integrity of the finished product.

\section{References}

1 Newton R, Ferlay J, Reeves G, Beral V, Parkin DM. Effect of ambient solar ultraviolet radiation on incidence of squamous-cell carcinoma of the eye. Lancet. 1996;347(9013):14501.

2 Ramberg I, Heegaard S, Prause JU, Sjö NC, Toft PB. Squamous cell dysplasia and carcinoma of the conjunctiva. A nationwide, retrospective, epidemiological study of Danish patients. Acta Ophthalmol. 2015;93(7):663-6.

3 Shields CL, Alset AE, Boal NS, Casey MG, Knapp AN, Sugarman JA, et al. Conjunctival tumors in 5,002 cases. Comparative analysis of benign versus malignant counterparts. The 2016 James D. Allen Lecture. Am J Ophthalmol. 2017;173:106-33.

4 Erie JC, Campbell RJ, Liesegang TJ. Conjunctival and corneal intraepithelial and invasive neoplasia. Ophthalmology. 1986;93(2):17683.

5 Li AS, Shih CY, Rosen L, Steiner A, Milman T, Udell IJ. Recurrence of ocular surface squamous neoplasia treated with excisional biopsy and cryotherapy. Am J Ophthalmol. 2015; 160(2):213-e1.
6 Palamar M, Kaya E, Egrilmez S, Akalin T, Yagci A. Amniotic membrane transplantation in surgical management of ocular surface squamous neoplasias: long-term results. Eye. 2014;28(9):1131-5.

7 Peksayar G, Soytürk MK, Demiryont M. Long-term results of cryotherapy on malignant epithelial tumors of the conjunctiva. Am J Ophthalmol. 1989;107(4):337-40.

8 Sturges A, Butt AL, Lai JE, Chodosh J. Topical interferon or surgical excision for the management of primary ocular surface squamous neoplasia. Ophthalmology. 2008;115(8): 1297-e1.

9 Sudesh S, Rapuano CJ, Cohen EJ, Eagle RC Jr, Laibson PR. Surgical management of ocular surface squamous neoplasms: the experience from a cornea center. Cornea. 2000;19(3): 278-83.

10 Tunc M, Char DH, Crawford B, Miller T. Intraepithelial and invasive squamous cell carcinoma of the conjunctiva: analysis of 60 cases. Br J Ophthalmol. 1999;83(1):98-103.

11 Arepalli S, Kaliki S, Shields CL, Emrich J, Komarnicky L, Shields JA. Plaque radiotherapy in the management of scleral-invasive conjunctival squamous cell carcinoma: an analysis of 15 eyes. JAMA Ophthalmol. 2014; 132(6):691-6.
12 Cerezo L, Otero J, Aragón G, Polo E, de la Torre A, Valcárcel F, et al. Conjunctival intraepithelial and invasive squamous cell carcinomas treated with strontium-90. Radiother Oncol. 1990;17(3):191-7.

13 Kearsley JH, Fitchew RS, Taylor RG. Adjunctive radiotherapy with strontium-90 in the treatment of conjunctival squamous cell carcinoma. Int J Radiat Oncol Biol Phys. 1988; 14(3):435-43.

14 Kenawy N, Garrick A, Heimann H, Coupland SE, Damato BE. Conjunctival squamous cell neoplasia: the Liverpool Ocular Oncology Centre experience. Graefes Arch Clin Exp Ophthalmol. 2015;253(1):143-50.

15 Laskar S, Gurram L, Laskar SG, Chaudhari S, Khanna N, Upreti R. Superficial ocular malignancies treated with strontium-90 brachytherapy: long term outcomes. J Contemp Brachytherapy. 2015;7(5):369-73.

16 Lecuona K, Stannard C, Hart G, Rice J, Cook C, Wetter J, et al. The treatment of carcinoma in situ and squamous cell carcinoma of the conjunctiva with fractionated strontium-90 radiation in a population with a high prevalence of HIV. Br J Ophthalmol. 2015;99(9): 1158-61. 
17 Lommatzsch P. Beta-ray treatment of malignant epithelial tumors of the conjunctiva. Am J Ophthalmol. 1976;81(2):198-206.

18 Walsh-Conway N, Conway RM. Plaque brachytherapy for the management of ocular surface malignancies with corneoscleral invasion. Clin Experiment Ophthalmol. 2009; 37(6):577-83.

19 Zehetmayer M, Menapace R, Kulnig W. Combined local excision and brachytherapy with ruthenium-106 in the treatment of epibulbar malignancies. Ophthalmologica. 1993; 207(3):133-9.

20 Shields JA, Shields CL, De Potter P. Surgical management of conjunctival tumors. The 1994 Lynn B. McMahan Lecture. Arch Ophthalmol. 1997;115:808-15.
21 Cohen VML, O’Day RF. Management issues in conjunctival tumours: ocular surface squamous neoplasia. Ophthalmol Ther. 2020;9(1): 181-90.

22 Stannard C, Sauerwein W, Maree G, Lecuona K. Radiotherapy for ocular tumours. Eye. 2013;27(2):119-27.

23 Soll DB, Harrison SE. Basic concepts and an overview of cryosurgery in ophthalmic plastic surgery. Ophthalmic Surg. 1979;10(8):31-6.

24 Wilkes TD, Fraunfelder FT. Principles of cryosurgery. Ophthalmic Surg. 1979;10(8): 21-30.

25 Copeland RA Jr, Char DH. Limbal autograft reconstruction after conjunctival squamous cell carcinoma. Am J Ophthalmol. 1990; 110(4):412-5

26 El-Assal KS, Salvi SM, Rundle PA, Mudhar HS, Rennie IG. Treatment of invasive ocular surface squamous neoplasia with proton beam therapy. Eye. 2013;27(10):1223-4.
27 Ramonas KM, Conway RM, Daftari IK, Crawford JB, O'Brien JM. Successful treatment of intraocularly invasive conjunctival squamous cell carcinoma with proton beam therapy. Arch Ophthalmol. 2006;124(1):1268.

28 Santoni A, Thariat J, Maschi C, Herault J, Baillif S, Lassalle S, et al. Management of invasive squamous cell carcinomas of the conjunctiva. Am J Ophthalmol. 2019;200:1-9.

29 Shields CL, Demirci H, Karatza E, Shields JA. Clinical survey of 1643 melanocytic and nonmelanocytic conjunctival tumors. Ophthalmology. 2004;111(9):1747-54.

30 Klefter ON, Rasmussen MLR, Toft PB, Heegaard S. Therapeutic options for conjunctival neoplasia. Expert Rev Ophthalmol. 2018; 13(1):17-31. 